Received: January 13, 2021 / Accepted: March 21, 2021 / Published online: July 2, 2021

The (C) Author(s) 2021. This article is published with open access at Academia Analitica

ORIGINAL SCIENTIFIC PAPER

UDC: 930.1:14 Ibn Khaldun

\title{
The Role of History and Problem of Method in Ibn Khaldun's Muqaddima
}

\author{
Kerim Sušić ${ }^{1}$
}

\begin{abstract}
The main purpose of this paper is to examine and discuss the importance of the method that Ibn Khaldun introduces in Muqaddima. The dimensions of the consequences of its application are particularly reflected through a completely new role of history as a science. For Ibn Khaldun, the new method with clearly established scientific principles should provide a crucial role in understanding the social laws and forces that determine the course of history. In considering Ibn Khaldun's thought, special attention is paid to the fact that he is an Arab-Islamic thinker from the $14^{\text {th }}$ century, which simply does not allow the study of his doctrine apart from the context of the time that he witnessed.
\end{abstract}

Key words: history, Ibn Khaldun, method, Muqaddimah, society

\footnotetext{
${ }^{1}$ K.Sušić

The First Bosniak High School

Petrakijina 22, 71000 Sarajevo, Bosnia and Hercegovina

(D) kerimsusic@gmail.com
} 


\section{Introduction}

There is a reason to ask a question how to approach the work of great thinker such as Ibn Khaldun. Probably the best answer lies in the opening statement of his most significant work, the Muqaddima², that warn the reader to the trap of history in the form of a misguided attitude and belief that the life circumstances of a nation, state, age or individual can't be changed. On the contrary, according to the time span, their living conditions change, which implies the contingency immanent to these phenomena, i.e. the inability to form them constantly in the same way (Ibn Khaldun 1958: 56-57). Therefore, Irwin's (2018: xiii) remark to contemporary interpreters of Ibn Khaldun's thought may make sense. They try in all possible ways to discover why this thinker is so important for understanding today's world that is predominantly determined by processes such as globalization and digitalization, the development of nation states, democracy and various forms of dictatorship. Paradoxically, and at least unexpectedly, his answer lies in the absolute irrelevance of Ibn Khaldun's ideas in relation to the modern world, because the conditions of their emergence are determined by the cultural-historical and spiritual-political circumstances of the time that Ibn Khaldun witnessed. Without going into the details of Ibn Khaldun's very rich and interesting biography, it is important to begin by pointing out a fact that should always be kept in mind when we try to understand his ideas, namely, Ibn Khaldun was an Arabic-Islamic thinker from North Africa who led a distinctive socio-political life, performing various functions within religious and state institutions in that area during the $14^{\text {th }}$ century. ${ }^{3}$

\footnotetext{
${ }^{2}$ Although today, due to its importance, it is most often considered as a separate work, Muqaddima is the title of Ibn Khaldun's work whose original intention was to facilitate understanding of historical events, and in fact is an introductory and inseparable part of his main work Kitâb al-ibâr wa diwanu al-mubtada' wa al-khabari fî ejjâmi al-'Arabi wa al-'Agami wa al-Berberi wa men âsarahum min dewî as-sultâni al-ekbari,. The first volume contains Muqaddima whose text is identical to that in the first printed edition prepared by the same editor 10 years earlier. Also, this first printed version of Muqaddima in Arabic was published in Bulaq near Cairo. Muqaddima in translation means prologue, introduction, and can also have the meaning of premise. The French orientalist Etiene Marc Quatremere prepared the first European complete edition of the Muqaddima in Arabic, which was published in 1858 in Paris, a year after his death. Then the Irish-French Orientalist William MacGuckin de Slane translates Muqaddima into French, which is the first translation of this work into one of the European languages, for more details about these editions and translations see Rosenthal 1958: c-civ. It is Franz Rosenthal who will prepare the first and, thus far, only complete English translation of the Muqaddimah, with an extensive preface and commentaries, which was published in 1958 in three volumes. Also, this translation will be used in the article, cf. Ibn Khaldun 1958.
}

${ }^{3}$ For more details on the life and work of Ibn Khaldun, see Enan 1941. 
Through two thematic blocks, special attention will be paid to the analysis of Ibn Khaldun's method, and the consequences of its application in understanding social laws and forces that in his opinion decisively determine the course of history, as well as the conditions of various social processes permeating its heterogenous, ambiguous and complex structure. In order to better understand the new role of history in Muqaddima, the theoretical assumptions of the most significant concepts of Ibn Khaldun's thought are also considered. In particular, this article seeks to delve into the complexity of the meaning of umran, as this concept represents the centre of Ibn Khaldun's thought, and is in fact the main feature of his intellectual efforts to overcome difficulties in understanding the social reality of his time, which in his opinion were largely caused by the inadequate role of history as a science.

Furthermore, this paper seeks to view Ibn Khaldun's thought in a context whose focus is not exclusively on harmonizing his ideas with the worldviews that result from the scientific contributions of the modern age, nor is it identical with the main tendencies of most contemporary interpretations that try to reconcile his teachings with the most important sociological perspectives. In contrast, the ideas and works of greats of the Western European thought, from the Renaissance to the present day, who share the same or similar subjects of scientific and research interest with Ibn Khaldun, can only serve to explain his thought mainly in comparative analyses aimed at identifying contrariety that essentially shape the relationship between their doctrines, and overall, the complex relationship between the two intellectual traditions. Everything else would be an intellectual adventure devoid of scientific basis, primarily due to the lack of facts that would indicate their real connection, which necessarily implies the impossibility of accurately determining Ibn Khaldun's influence on the formation of the views of these thinkers.

\section{The Background, Motive and Reason of Ibn Khaldun's Request for New Methodology}

At first, it should be noted that Ibn Khaldun primarily sought to revise the previous role of history by establishing a completely new method based on principles that were clearly separated from those that could be found in the methods of the then research of social reality, and especially history itself. This breakthrough of Ibn Khaldun, or rather a radical turn in relation to his predecessors, will cause the development of two essential processes inherent in his thought. Namely, in his opinion, history should thus gain a new, far more significant status, which primarily implies an equal position of history in relation to previously recognized 
sciences, and consequently, the expansion of its own subject of research by including in its scientific interest all those phenomena of social reality that are today largely encompassed by the scientific inventory and research methods of contemporary sociology.

It is difficult to single out the main motives that prompted Ibn Khaldun to make this move, and thus to write Muqaddima, without failing into a kind of reductionism in interpreting and analyzing his thought. What is obvious is the fact that he was disappointed with the consequences of the constant devastation of cultural-historical heritage and the highest civilizational achievements of his predecessors, which largely shaped the social reality of the then Islamic world. Therefore, Ibn Khaldun sought to decipher the essence, meaning and purposefulness of social processes and changes, and the historical circumstances that caused such a state. Also, in this context, one should definitely take into account his clearly expressed dissatisfaction with previous intellectual and scientific answers and his a priori rejection of all unscientific interpretations referring to escape or to facing difficulties arising from the consequences of certain social changes, which are mainly conditioned by a lack of understanding of the causes of their occurrence: "Most of humanity seeks to escape the terrifying reality of human history, to make some sense of events, to hope for something better (an afterlife? a redemptive life? remembrance?) than what we have" (Ruiz 2011: 6). In addition, collective and personal tragedies, as well as specific life and political circumstances, and the already mentioned constant disappearance of social communities in different epochs, also represent the starting point of Ibn Khaldun's intellectual efforts in order to offer scientifically based answers to questions that he considered that they have been omitted from most of his predecessors or, at best, mistreated.

Muqaddima, one of the most significant works of medieval social thought, which, among other things, is a draft of Ibn Khaldun's theoretical approach to researching these problems, is also the starting point of many contemporary interpretations whose primary goal is determined by the intention to use it in understanding the major social problems of the modern world. Therefore, today it is generally believed that the main motive of Ibn Khaldun's thought efforts was directed towards the establishment of a new science of society, which for many authors is the basis of the claim that Ibn Khaldun is actually the founder of sociology as a modern scientific discipline. 
Some authors will go a step further in their qualifications of his thought, seeing Ibn Khaldun as the originator of the philosophy of history ${ }^{4}$, or, on the other hand, as a forerunner of structuralist perspectives in sociology, whether it is conflict structuralism such as Marxism ${ }^{5}$ or consensus theory which is developed from the writings of the French sociologist Emile Durkheim. Therefore, here we can agree with al-Azmeh (1981: v) according to whom: "Ibn Khaldun has almost become an intellectual household name. In different ways, sociologists, economists, philosophers of history, as well liberals, Marxists, Arab nationalists, and fascists have all claimed him as their own." Mostly, such definitions and understanding of Ibn Khaldun's thought are a consequence of the demands of a process that essentially shapes the modern paradigm of interpreting classical Arab-Islamic philosophical and social thought.

In contrast to these interpretations, and within the consideration of Ibn Khaldun's views on the nature of human society, it should be noted that Ibn Khaldun's contributions in the context of the history of social thought are largely conditioned by the aforementioned facts in the introduction, namely, that he was an ArabIslamic thinker of the Middle Ages. His views and research on almost all major social phenomena are rooted in the spiritual-cultural and political paradigm that strongly shaped the social reality of the then Muslim states in North Africa. With this in mind, it is therefore inappropriate to use exclusively the attributes inherent in modern science and culture when evaluating Ibn Khaldun's views.

Furthermore, in this context it is also important to point out that mainly under the pretext of comparative research and the intention to learn about the highest intellectual achievements of other civilizations, there is an obvious effort to emphasize the superiority of the philosophical and scientific heritage of Western European culture and civilization. Such an approach is characteristic of most

\footnotetext{
${ }^{4}$ „In his chosen field of intellectual activity he appears to have been inspired by no predecessors and to have found no kindred souls among his contemporaries and to have kindled no answering spark of inspiration in any successors; and yet, in the Prologomena (Muqaddamat) to his Universal History he has conceived and formulated a philosophy of history which is undoubtedly the greatest work of its kind that has ever yet been created by any mind in any time or place." Toynbee 1956: 322.

${ }^{5}$ In contrast to approaches that seek entirely to subordinate and interpret Ibn Khaldun's doctrine from the standpoint of Marxism, an interesting and acceptable connection between Marx and Ibn Khaldun is made by Dhaouadi (2006: 59) in his study: "With this key statement that the economic forces have decisive role in shaping the very nature of human societies, Ibn Khaldun can rightly be considered as a forerunner of Marxist thought. The substance of the above observation is hardly different from that of Marx..." In the next paragraph, in order to avoid entirely "marxise" Ibn Khaldun's thought, he puts the note that it must not be concluded that two thinkers have agreements on all levels. This remark is very important because it indicates the negative consequences of the process of de-Islamization and Westernization of Ibn Khaldun's thought (cf. Ibid: $60)$.
} 
Orientalists whose views are closely linked to the political and economic circumstances of the $19^{\text {th }}$ and $20^{\text {th }}$ centuries as well as the colonial expansion of Western European countries. The one-sidedness of Orientalism and its methodological approach to the study of Islamic culture and civilization will also become a major feature of most contemporary interpretations of Ibn Khaldun's thought. It is about the impossibility of overcoming the limitations caused by the study and evaluation of other cultures and traditions within categories that are exclusively the heritage of Western European civilization.

On the other hand, the answers of Muslim authors were mostly caused by the inferiority complex, which is reflected in the efforts to single out Arab-Islamic thinker like Ibn Khaldun at all costs, in comparison with the great thinkers of Western European thought, by declaring them the forerunner of Montesquieu, Machiavelli, Vico, Marx, Durkheim and others (cf. Sunar and Yasliçimen, 2008: 417). As a consequence of such an endeavour, which seeks to justify its superiority, there is necessarily a neglect of the real richness and significance of the ideas of this tradition as a whole.

All these tendencies, that have become the dominant paradigm in the study of Ibn Khaldun, will necessarily produce a series of misperceptions about his thought and a multitude of superficial generalizations that will divert the focus from his real contribution. They will especially marginalize Ibn Khaldun's critique of the previous understanding of the role of history and its application in explaining the basic laws of social events. This critique is based on two remarks that will essentially shape his entire thought. The first remark refers to the absence of a method, which gave philosophical character to Ibn Khaldun's theory, because the implementation of the method in history presupposes a new relationship towards Being and world. For Ibn Khaldun, this resolution of the methodological question also changes the cognitive goals of history because it is now deeply grounded in philosophy as he claimed in his foreword to Muqaddima: "The inner meaning of history, on the other hand, involves a speculation and an attempt to get at truth, subtle explanation of the causes and origins of existing things, and deep knowledge of the how and why of events. History, therefore, is firmly rooted in philosophy. It deserves to be accounted a branch of philosophy" (Ibn Khaldun 1958, 6). These changes caused completely new understanding of history as a science, which will be discussed in more details later. The second remark, which is closely connected with the previous one, refers to the unscientific character of history and consequently to its subordinate status in relation to other sciences. Exactly in this, Ibn Khaldun found the impetus for a critique of his own tradition and its relation to history. Additionally, Ibn Khaldun 
thus create a basis for redefining history in the form of a more precise definition of its subject of research. This became apparent through the introduction of a new object into the focus of his research, and that is umran: "It should be known that history, in matter of fact, is information about human social organization [umran], which itself is identical with world civilization [umran]. It deals with such conditions affecting the nature of civilization [umran] as, for instance, savagery and sociability, group feelings [assabiya], and the different ways by which one group of human beings achieves superiority over another" (Ibn Khaldun 1958: 71).

From this critique one can read the main intention and reason of Ibn Khaldun's request for the introduction of the method. Compared to his predecessors for whom history had a normative and descriptive character, Ibn Khaldun was the first historian to adopt a scientific approach to history. The initial step in realization of this intention is the introduction of a method that provides the prerequisites for scientific analysis of history. As Charles E. Butterworth claimed in his interview, the main goal of the Muqaddima is that: "Ibn Khaldun is trying to give us a science of history, to lay down the fundamentals, so that history can be done correctly"(Butterworth 2012: 2:30). Consequently, this should make it possible to overcome the shortcomings of earlier Arab historians and, more importantly, will identify the principles for the understanding of the umran, a key concept that Ibn Khaldun introduces in his doctrine (cf. Butterworth 2012).

\section{Introduction of the Method and its Significance for Understanding History}

At first sight, it may seem that the problem of method in Muqaddima is completely marginalized, since Ibn Khaldun in just one page in short theses indicated the basic principles of the methodology that would be applied in his research. However, when the book is read in its entirety, then it becomes clear that it is designed to address and resolve methodological issue. For failing to recognize this fact, many interpreters neglect this aspect of Ibn Khaldun's thought, considering it less important in the context of emphasizing the key characteristics of his doctrine. Therefore, they would mainly focus on discussions about Ibn Khaldun's role for various aspects of science, whether it is sociology, the history of philosophy or economy. But, generally speaking, the question of method is crucial for any science, as it first reveals whether it is something new and revolutionary in it. 
Referring to the causes of shortcomings and misconceptions in Arab history and showing that they are the main culprit for which most of its part is burdened with untruths and that the authors of historical works have not been able to identify causes of certain events or try to discover their purpose, Ibn Khaldun will try to transfer this endeavour to all phenomena, and thus to history as a science: "Untruth naturally afflicts historical information. There are various reasons that make this unavoidable. One of them is partisanship for opinions and schools [...] Another reason making untruth unavoidable in historical information is reliance on transmitters [...] Another reason is unawareness of the purpose of an event [...] Another reason is unfounded assumption as to the truth of a thing [...] Another reason is ignorance of how conditions conform with reality" (Ibn Khaldun 1958: 7172). Following this, Ibn Khaldun presents, through a critical analysis, the real reasons for the state of history and realize that the problem of method was crucial for the constitution of history as a science. Therefore, his critique should be understood as a starting point of a new methodology. Also, for Ibn Khaldun, critical analysis was necessary to uncover the obstacles that made history unscientific. In order to understand its meaning the following words should be considered: "From a methodological point of view, this is not a critique in terms of an exact reexamination of historical sources that were not even the subject of historical research an evaluation at the time. Ibn Khaldun's critique is essentially directed towards the general and the theoretical, i.e. its basic goal was to determine the general conditions of correct historical thinking" (Sušić 1972: 83).

Ibn Khaldun's new method will radically change the role of history, which until then was mainly preoccupied with mere descriptions and enumerations of events and dates, and dealt with the biographies of famous people from the past, dynasties and their rulers, often with the help of fantasies and speculation. Numerous examples are given in the Muqaddima depicting such a state of history that necessarily required the introduction of order and the creation preconditions for correct historical thinking. In an effort to reject these tendencies that completely hide the true meaning of historical events and to constitute history as a rigorous science whose primarily goal should be to study the essence and causes of historical events, Ibn Khaldun will use a critical methodology to change its character and subject.

Considering that human society (umran) is the stage of historical events, Ibn Khaldun will open a completely new and original page in the history of human thought. In order to define this concept as clearly as possible, Ibn Khaldun starts from the premise that man is first and foremost a social being, which implies that 
man's existence is conditioned by the necessity of social organization (cf. Bučan 1976:28). It is quite clear, as Ibn Khaldun himself admits, that this idea was taken from Greek and Arab-Islamic philosophers, i.e. by adopting their ideas and methodology, Ibn Khaldun strives to completely changed historical research, which he then utilizes to compile a study of the society in which he lived. The fact that Ibn Khaldun and later European political economists, historians, and sociologists were influenced by the same philosophical ideas accurately explains the similarity between the methodology and the principles they employ in their studies (cf. Dale 2015: x-xi). In line with the above mentioned, Ibn Khaldun says that: “... social organization is necessary to the human species. Without it, the existence of human beings would be incomplete. God's desire to settle the world with human beings and to leave them as His representatives on earth would not materialize. This is the meaning of civilization [umran], the object of science under discussion" (Ibn Khaldun 1958: 91). Thus, human society, its phenomena, nature and processes, as well as a unique understanding of the causes of the permanent changes that take place in social life, will become the main subject of the study of history as a science. This turn in the form of the priority of studying the essence and nature of society, as well as the principles of social life, will lead Ibn Khaldun to the science of society (ilm al-umran), i.e. to the search for assumptions of proper historical thinking and research (cf. Sušić 1972).

On the other hand, taking into account the development of the idea of history and its status in antique where it was subordinated to practical and theoretical sciences, it can be wrongly concluded that Ibn Khaldun in establishing history as a rigorous science completely abandoned the principles of ancient philosophy. For the Greeks, the primary task of history is to explain past action. Since they belong to the world of change, and in accordance with the dominant Greek - philosophical thought cannot be known, then historical knowledge is impossible, because everything that can be the subject of knowledge is also immutable (cf. Collingwood 1993). The philosophical background of such an idea of history rests on the view that there are objective realities that precede the unstable knowledge of history.

Ibn Khaldun saw that history has a special significance because it is directed to society to a much greater extent than other sciences. His originality lies precisely in the fact that he realized that history should be independent science and that it was precisely his task to correct it. However, this did not imply a radical abandonment of the existing principles of scientific research, as well noted by Muhsin Mahdi in his study of Ibn Khaldun: "But he did not think that the construction of the new science required considerable changes in the established principles of scientific 
investigation, or questioning the validity of the norms established by political philosophy. On the contrary, he found that only by admitting the validity of these principles and norms as developed by the ancients could the new science be constructed. This is clearly shown by the fact that he applied these same principles and norms in constructing the new science of history" (Mahdi 1971: 10).

\section{Conclusion}

Great thinkers like Ibn Khaldun dealt with universal issues and ideas concerning every human being. Without neglecting the numerous and very important interpretations, such as some that we have mentioned here, it is nevertheless more important to pay attention to what Ibn Khaldun says in Muqaddima in order to fully comprehend the originality and real contributions of his doctrine. This is especially significant in the context of understanding Ibn Khaldun's reflections on the method since it is the most important aspect of his thought, which is often unreasonably neglected and marginalized. Such a treatment of Muqaddima is caused above all by a number of reasons of the scholars which differ mainly from Ibn Khaldun's motivations to write such a work.

Taking into account the stated facts, it is difficult to agree with mostly pretentious contemporary qualifications of Ibn Khaldun. However, what can be said with certainty is that Ibn Khaldun is a historian par excellence who sought to provide a scientific character to history. Primarily in this form one should look at Muqaddima which is conceived as a resolution of the methodological issue in history. It is based on clearly explained principles derived from Greek and Arabic - Islamic philosophy. Regardless of the consequences of such an intention, Ibn Khaldun inevitably had to reflect in detail on various ideas and problems concerning human being. The way he treated them would create outlines of what would later in the modern age become different scientific and philosophical disciplines such as sociology, philosophy of history or economy. 


\section{References}

Al-Azmeh, A. (1981). Ibn Khaldun in Modern Scholarship: A Study in Orientalism. London: Third World Centre for Research and Publishing.

Bučan, D. (1976). "Realistički racionalizam Ibn Halduna", In Ibn Haldun: Iz Muqaddime (edited and translated by Daniel Bučan). Zagreb: JAZU, Zavod za filozofiju znanosti i mir, pp. 9-58.

Butterworth, Ch. E. (2012). "Scholar's Chair interview: Dr. Charles E. Butterworth - Ibn Khaldun's Muqaddimah", Interview by Khalil Shadeed. YouTube, uploaded by Khalil Shadeed, 28 Oct. 2012, https://www.youtube.com/watch?v=VWyYoW ZfY0.m

Collingwood, R. G. (1993). The Idea of History: With lectures 1926 -1928. Revised Edition with an Introduction and additional material edited by Jan van der Dussen. Oxford: Oxford University Press.

Dale, S. F. (2015). The Orange Trees of Marrakesh: Ibn Khaldun and the Science of Man. Cambridge MA \& London: Harvard University Press.

Enan, M. A. (1941). Ibn Khaldun: His Life and Work. Lahore: Sh. Muhammad Ashraf.

Dhaouadi, M. (2006). "The Concept of Change in the Thought of Ibn Khaldun and Western Classical Sociologists", Islâm Araştirmalari Dørgisi, vol. 16, pp. 43-87.p

Khaldun, I. (1958). The Muqaddimah: An Introduction to History. Translated from the Arabic by Franz Rosenthal in 3 vols. London: Routledge \& Kegan Paul.

Irwin, R. (2018). Ibn Khaldun: An Intellectual Biography. Princeton: Princeton University Press.

Mahdi, M. (1971). Ibn Khaldun's Philosophy of History: A Study in the Philosophic Foundation of the Science of Culture. Chicago: The University of Chicago Press.

Rosenthal, F. (1958). Khaldun Translator's Introduction Khaldun. In Ibn Khaldun, The Muqaddimah: An Introduction to History. Translated from the Arabic by Franz Rosenthal in 3 vols. London: Routledge \& Kegan Paul, pp. xxvii-cxv. 
Ruiz, T. F. (2011). The Terror of History: On the Uncertainties of Life in Western Civilization. Princeton \& Oxford: Princeton University Press.

Sunar, L. and Yasliçimen, F. (2008). "The Possibilities of New Perspectives for Social Sciences: An Analysis Based on Ibn Khaldun's theory of Umran", Asian Journal of Social Science, vol. 36, no. 3-4, pp. 408-433.

Sušić, H. (1972): Ibn Haldun i njegov značaj za sociologiju. Sarajevo: University of Sarajevo, PhD dissertation.

Toynbee, A. J. (1956). A Study of History, vol. III. London \& New York: Oxford University Press. 